\title{
A COMPARATIVE STUDY OF TOURISM EDUCATION ON VOCATIONAL LEVEL IN HUNGARY AND FINLAND
}

\section{A SZAKKÖZÉPISKOLAI TURISZTIKAI OKTATÁS MAGYARORSZÁGON ÉS FINNORSZÁGBAN - ÖSSZEHASONLÍTÓ TANULMÁNY}

\author{
Anita Mondok ${ }^{1}$ \\ Tourism and Catering Department, Business Administration Faculty, John von Neumann University, \\ Hungary
}

\author{
Key worlds: \\ VET \\ tourism \\ Hungary \\ Finland \\ Kulcsszavak: \\ szakképzés \\ turizmus \\ Magyarország \\ Finnország
}

\begin{abstract}
The rapid growth of tourism in Hungary and the labour migration to abroad resulted in a serious labour shortage in the industry. One of the sources of skilled and motivated workforce is the system of tourism vocational education and training, which can just slowly react to market changes due to its inertness. In addition, the highly centralized system provides low-level of freedom to respond to regional differences, as the National Core Curriculum and its related regulatory documents are compulsory for the institutions and maintainers implementing them.

This paper seeks for possible solutions to the prevailing challenges by a comparative examination of the tourism VET system in Finland and Hungary. As a result the author propounds possible alternatives to develop secondary tourism education.

Összefoglalás

A turizmus gyors növekedése és a munkaerő külföldre vándorlása Magyarországon is komoly munkaerőhiányt eredményezett az iparágban. A képzett és motivált munkaerö egyik kibocsátó forrása a turisztikai szakképzés rendszere, amely a rendszer tehetetlensége okán csak lassan képes reagálni a piaci folyamatokra. Mindemellett az erösen centralizált rendszer elenyésző lehetőséget biztosít a területi különbségek figyelembe vételére, hiszen a Nemzeti Alaptanterv és kapcsolódó szabályozó dokumentumai szúk mozgásteret biztosítanak az azt végrehajtó intézmények és fenntartóik számára.

Jelen cikk a magyarországi és a finnországi turisztikai szakképzési rendszer összehasonlító vizsgálatával igyekszik megoldást találni a hazai kihívásokra. Ennek eredményeként a
\end{abstract}

\footnotetext{
1 Contact Author. Tel.: +36 56516066

E-mail address: mondok.anita@gk.uni-neumann.hu
} 

megfogalmaz.

\section{Introduction}

Vocational education and training (VET) includes education and training programmes designed for, and typically leading to, a particular job or type of job. Commonly practical training is involved as well as the learning of relevant theory. It is distinct from academic education, as the focus of educational programme is on enhancement of job-specific skills, abilities and knowledge.

In Hungary since 2000, the content of teaching and learning in schools has been controlled by a three-tier curriculum regulation. The first level is the National Core Curriculum (NCC), what was thoroughly renewed in 2012 and introduced gradually from 2013. NCC must be followed by all institutions and stakeholders of public education as a strategic document. In NCC the ideological-theoretical-philosophical grounds for the subject areas, the phases of school education in terms of content and the developmental tasks are defined properly and applied to all schools until the upper age limit of compulsory schooling.

Curriculum and methodology are strengthened by the second level of content regulation. This consists of framework curricula based on the NCC and issued by the minister of education. Distinct curricula have been developed for vocational secondary schools, for vocational training schools and for special vocational schools on the basis of educational sector and industry.

The third level of regulation is the pedagogical programme of schools including the local curriculum and the educational-teaching programme. This curriculum is compiled by the school teachers and the school-level content regulation documents are adopted by the teaching staff following an approval of school maintainers.

Helsinki Communiqué on Enhanced European Cooperation in Vocational Education and Training [1] pointed out that "policies should engage all young people in vocational training and/or higher education, ensuring at the same time that they acquire skills and competences relevant to the labour market and to their future lives. Furthermore, policies should serve people already in working-life by ensuring possibilities for further development throughout their careers. VET systems should, as part of flexible educational pathways, increasingly enable progression to further education and training, especially from VET to higher education". Although VET in tourism has undergone three curriculum modifications over the last six years in Hungary, despite its learning outcome-based structure; it does little to meet the real expectations of the labour market. In addition, the interests of secondary schools and higher education institutions conflict with those graduates who wish to qualify for tourism but do not want to obtain a Bachelor's degree. This conflict is the base for further examination and a comparative study in the next sections.

\section{Methods}

The secondary research based on literature review. It was completed by assessment of legislation of higher education system and the education of tourism and curriculum and procedural documents accessed at websites of the Hungarian VET institutions. Many Hungarian and Finnish scientific publications were available, which provide substantial theoretical background.

\section{Results and Discussion}

\subsection{The system of VET in Hungary}

The governance of the Hungarian educational and qualifications system is distributed between Ministry for National Economy (MNE) (vocational and adult education and nonformal education) and Ministry of Human Capacities (general and higher education). 
Depending upon the economic sector, authority for vocational qualifications can be allocated between the MNE and other sector-related ministries.

The Minister of National Economy is responsible for the legislation, the National Module Map, the vocational training framework curricula and the adult training system. His job is supported by the National Vocational and Adult Training Council (NVATC) which organization operates as a national body to make decisions, support decision making or to introduce proposals. The operative tasks of the vocational education and adult training are performed by National Office of Vocational Education and Training and Adult Learning (NOVETAL), controlled by MNE. Main responsibilities include planning, implementing and monitoring of VET policy and examination of impacts, exercise of maintenance rights of VET schools and keeping contact to them. Besides that NOVETAL performs tasks related to the registration, authorisation, control and statistical data gathering of adult training institutions and adult training experts as well as collects data on vocational qualifications and make them available on the web [2].

National Vocational Qualifications Register (NVQR) defines the state recognised qualifications what was delivered firstly in 1994 and thoroughly revised and substantially renewed in 2004. Government Decree No. 150 issued in 2012 includes NVQR, the procedure of modifying NVQR and the list of qualifications. The latest modification was published in 2016 and the currently valid version defines 760 (full, partial and add-on) qualifications belonging to 22 profession groups. NVQR and the National Module Map are connected; an online search platform supports web visitors to get descriptions of the modules of qualifications or information how qualifications are linked to one another. Ministerial decrees specify vocational examination requirements (VER) for the different sectors and contain regulations and requirements of each vocational qualification. VER includes competences and learning outcomes related to each module necessary for employability [3]. While the vocational examination requirements (VERs) of NVQR qualifications are issued by the Minister responsible for the concerned qualification, vocational programme requirements (VPRs) are approved and included in the register by the HCCI Programme Committee. The aim of vocational programme requirement is to ensure other vocational trainings outside the NVQR to be implemented according to a unified system of requirements as well.

The NVQR differentiate specific qualification levels: (i) partial which includes only a limited number of modules, (ii) full qualification which comprises all modules of a qualification and (iii) add-on qualification containing additional module(s) built on a full qualification. Partial qualification is designed to support a simpler occupation or a narrower scope of task in different occupations and designed to meet the requirements of at least one occupation. Partial qualifications may be obtained in different levels of education. Some of the lower level partial qualifications fulfils the general needs of the labour market and also facilitate people to achieve full qualification in association with the principle of lifelong learning. The add-on qualification is established a certain full qualification registered in the NVQR. Add-on qualification generally provides education for performing higher-level or more specified jobs. Usually it has own modules qualifying the learner for delivering further scope(s) of activities. One add-on qualification may be initiated several qualifications, however not all full qualifications has partial or add-on variant.

It is necessary to mention the Hungarian Chamber of Commerce and Industry (HCCI) as having a substantial role in the operation of the regulation system of adult training. Adult Training Act vests material power, in certain cases exclusive decision-making competences in the Chamber, which thus can properly represent the interests of economy in adult training [2].

\subsection{The system of VET in Finland}

In the Finnish nation, education played a determinant role towards a modern society. Equal access to education and training is one of key principles of the Finnish education system. Therefore a single structure and governance is used for compulsory education. The Ministry of Education and Culture is competent to govern strategic and normative operation of VET sector and also manage development on national level. The Ministry grants 
authorisation to educational institutions to allow VET provision. The government determines national objectives, qualifications structure and core subjects included in core curricula, number of students, language of instruction, locations, special educational tasks and other issues as provides the most of funds of VET financing.

Institutions providing VET are responsible for organising education based on national qualification requirements in their professional fields with a continuous matching with the local labour markets' needs. VET providers have freedom in the elaboration of type of education and training provided and teaching method by keeping the restraints of their authorisation from the Ministry of Education and Culture. VET providers have a wide variety of form of operation; they may be local authorities, and municipal training consortium, foundations or other registered associations or state companies.

The system of education is highly permeable, the progression to higher levels of education is provided in several ways. School-based programmes, apprenticeship training and competence-based qualifications are the forms of vocational education and training. Apprenticeship training includes courses at vocational institutions, where the share of workbased learning is high (70\%-80\%). This type of training is mostly chosen by adults as well as competence-based qualifications. Almost 300 further and specialist qualifications in different fields are available in addition to the 52 vocational qualifications offered (they were fundamentally reformed in 2015). Vocational and further vocational qualifications are offered at upper secondary level and may be achieved by completion of competence tests, independently of how vocational skills were acquired. The specialist vocational qualification is available at post-secondary, non-tertiary level [4].

The single national-level vocational competences are ensured by the National Qualification Requirements. NQR is a foundation for evaluating learning outcomes, which requirements were compiled by the Finnish National Board of Education (FNBE). The development of NQR was a long process incorporating all stakeholders, e.g. student unions, organisations of employers, trade unions and the Trade Union of Education. Not just in the proceeding of development of NQR but in other tasks the cooperation to the labour market players is considered essential. Representatives of businesses perform in local curricula development, training and skills demonstrations' organization and planning, and they attend to regional training and qualification committees. The evaluation of skills demonstrations in upper secondary qualifications and competence tests in competence-based qualifications are also belong to their assignments.

The changing requirements of labour market generated the need to improve the flexibility of vocational qualifications. More opportunities are available, a degree of individualisation of qualifications can be achieved (e.g. modularisation to include modules from other vocational qualifications (incl. further vocational qualifications and specialist vocational qualifications) or polytechnic/applied sciences degrees). Upper secondary VET studies are established on individual study plans, including both compulsory and optional modules. This system helps to develop individual learning paths and boost their motivation to conclude their studies. This is also a tool for local or regional development as gives opportunity to education providers meet the demands of the labour market.

Vocational institutions can specify as selection criteria work experience and other comparable factors, e.g. entrance and aptitude tests. Obtaining VET qualification is socially accepted, more than $40 \%$ of the primary school graduates start upper secondary VET studies (mostly at vocational institutions) right after the completion of general education. All VET programmes include an on-the-job training section with a period of minimum six months [5].

Technology, transport and communication, social services are the mostly chosen fields of vocational education. The number of male and female learners is almost equal; however, the proportion varies greatly from sector to sector.

Choosing the profession of VET teacher is attractive; the number of applicants is much higher than the admission capacity in vocational teacher training programmes.

The state makes huge efforts in promoting participation in VET. Finland legislatively maintains an unpaid study leave system. Employees working for the same employer for at least one year may take for a maximum period of two to five years. An education and social guarantee is offered for young people by providing a place in secondary education or after 
graduation a job, on-the-job training, a student place, or a period in a workshop or in rehabilitation within three months of becoming unemployed. Youth workshops provide training and work experience placements to unemployed people under the age of 29. Guidance and counselling services are provided within the education system what is supported by the guidance services of the public employment offices. Since the introduction of comprehensive school system in the mid-1970s periods of work experience has been part of basic education to become learners acquainted with the world of work. A flexible component in basic education was introduced in 2010 by providing longer period for work experience. Graduates of basic education can choose additional education for 10th grade to help and encourage young people to go on upper secondary level. The FNBE operates a national application system, a comprehensive online information and application platform. A preparatory instruction and guidance was also introduced to lower the threshold for VET and to reduce dropout [5].

AVET system reform is currently undertaking by the government to re-establish VET legislation and the financing system, and to encourage learning at the workplace.

\subsection{The lessons learnt - what to adopt from the Finnish VET system}

Vocational education and training system cannot be separated from public education. Changes within the VET system cannot lead to the solution of the basic problems of vocational training in schools, and the fundamental reform of the whole public education system is essential. Steps must be taken to ensure the conditions of tailored education and sufficient competence development of students. The higher the autonomy level of an institution, the wider is its opportunities to react to market changes and the special needs of pupils. It is also necessary to ensure the requirements of education to adapt to target groups and geographical differences while the elimination of segregation must be in focus.

In Hungary the field of institutional education, education policy and education administration decisions are essentially carried out with the exclusion of the parties concerned, social coordination mechanisms do not work. The professional preparation of decisions, if any, is one-sided, and only one selected part of the relevant professional is involved.

Compared to Finland, the professional autonomy of educational, educational institutions and teachers is extremely low in Hungary. The management and maintenance of the institutional system, which carries out the tasks of education and education, is overcentralized, the organizational and economic independence of the institutions is minimal in relation to the importance of local decisions.

The state does not provide the financial conditions necessary for the optimal functioning of education and training (the government expenditure on education in Hungary is $4.58 \%$ of GDP, in Finland $6.2 \%$ (2015)[6]. In the nationalized system, infrastructure and pedagogical development cannot be covered by budget money. Salary increases do not reach the national average, and the average salary of teachers remains well below the average salary of graduates. In addition, cost planning is inadequate.

In Hungary, inequality in school is extremely high. In international comparison, selection and segregation are well above average. This condition is a serious threat to social inclusion and a source of prejudice. As a result of educational policies that effectively reduce inequalities, reduce social tensions, employment indicators improve, labour productivity increases, the country is growing in all social groups, society and economy are developing.

In the Hungarian education system, the school structure does not change, and the system that serves the once important social changes no longer meets the needs. The school structure provides a framework for extreme selection, increasing inequalities. In this structure, the positioning of modern vocational training is unresolved.

In Hungary, vocational training still prepares for immediate work after finishing school and does not apply the principle of preparing for lifelong learning. The system of vocational training is rigid, unable to adapt to the changing needs of the economy and society in general. Pedagogical problems related to inequality in the system of vocational education institutions are concentrated. 
In order to improve education and education, a system of teacher qualification, supervision and internal evaluation processes, formed since 2015, is unsuitable for fulfilling the tasks of quality development; it is an unnecessary burden for institutions and teachers.

\subsection{The direction of development since 2010 and current strategies}

The direction of change in education policy from 2010 turned to the opposite. Positive changes towards professional progression have come to an end, and new processes have begun. The most significant changes are the followings: (i) institutional and pedagogical autonomy is reduced, (ii) content control is very centralized, which prevents the development of competence-based education and makes pedagogical differentiation hard, (iii) public education is seriously underfunded, (iv) the level of inequality and segregation is rising and (v) the level of education in Hungary is decreasing (based on PISA-test results), the rate of early school leavers is increasing and institutions have a decreasing opportunity for talent management.

Ministry for Innovation and Technology launched an unpublished strategy for VET education on 14 March 2019 with the title of 'Vocational Training 4.0 - Medium-Term Policy Strategy for VET and Adult Education'. The new system would be launched by the Ministry in September 2020. To be realised, three laws and 19 regulations have to be amended / issued. The Act on Vocational Training is fundamentally amended and is separated from the Public Education Act. Three pillars of the new system are: career opportunities, attractive environment and modern, relevant knowledge of professional teachers and relevant content. Some introduced features of the new system are followings: - renaming of the school types, IT-based competency assessment rather than using entry exams, - strengthening career orientation, - introduction of workshop-type activities, - education of one foreign language (preferably English), - professional exam after graduation [7].

\section{Conclusion}

Consequently, establishing linkages between the educational institutions and businesses is beneficial for school-to-work transitions. Standardization and development of a commonly certified system of on-the-job training processes has effect on the expansion of the transferability of occupation-specific skills between businesses. Qualification based on competence assessments helps to validate previously achieved work experience. The inclusion of social partners, e.g. trade unions into the establishment of institutional linkages between VET and labour market increases the degree of efficiency and acceptance. To consider student union as a VET stakeholder improves the satisfaction of learners. Increase in merit of VET teacher profession is based on government incentives and financing.

Furthermore, general education can foster the participation and good performance of learners in VET by high level of skill enhancement and provision of individual learning paths.

In Finland single governance of education helps to introduce comprehensive reforms and eliminate dead ends in the secondary education system.

\section{Acknowledgement}

This research is supported by EFOP-3.6.1-16-2016-00006 "The development and enhancement of the research potential at John von Neumann University" project. The Project is supported by the Hungarian Government and co-financed by the European Social Fund. 


\section{Bibliographical References}

[1] European Ministers of Vocational Education and Training (2011): The Helsinki Communiquéon Enhanced European Cooperation in Vocational Education and Training. Available:

http://www.cedefop.europa.eu/files/helsinkicom en.pdf. [Accessed: 30-Jan-2019].

[2] Unknown author (2016): Spotlight on VET 2017 - Hungary, European Centre for the Development of Vocational Training, Thessaloniki, Greece. Available: http://www.cedefop.europa.eu/files/8126 en.pdf. [Accessed: 10-Feb-2019].

[3] Farkas, P. et al. (2016): Vocational education and training in Europe - Hungary. Cedefop ReferNet VET in Europe reports. Available: http://libserver.cedefop.europa.eu/vetelib/2016/2016 CR HU.pdf. [Accessed: 10-Feb-2019].

[4] Unknown author (2016): Spotlight on VET 2016 - Finland, European Centre for the Development of Vocational Training, Thessaloniki, Greece. Available: http://www.cedefop.europa.eu/files/8100_en.pdf. [Accessed: 10-Feb-2019].

[5] Koukku, A. - Kyrö, M. - Volmari, K. (2014): Finland VET in Europe - Country report 2014. Finnish National Board of Education, Helsinki, Finland. Available: https://cumulus.cedefop.europa.eu/files/vetelib/2014/2014_CR_FI.pdf. [Accessed: 13-Feb-2019].

[6] https://ec.europa.eu/eurostat/documents/4187653/7825806/IMG+graph+news+Education.jpg. [Accessed: 13-Feb-2019].

[7] http://ckpinfo.hu/2019/03/23/a-szakkepzes-4-0-strategia/. [Accessed: 13-Feb-2019]. 
(idi) 